Mitteilungen der Österreichischen Geographischen Gesellschaft,

155. Jg. (Jahresband), Wien 2013, S. 27-44

\title{
Multi-Speed European Union: The Schengen Agreement and Perceptions of its Spatiality in Central Europe
}

\author{
Petr Dostál, Prague [Praha]*
}

with 3 Fig. and 4 Tab. in the text

\section{Contents}

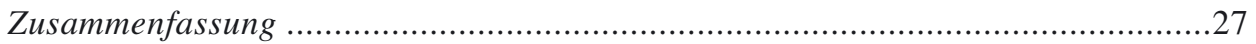

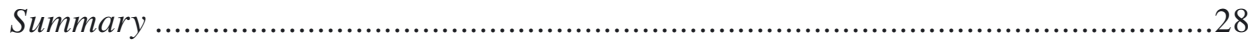

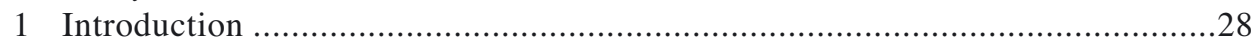

2 Multi-speed European Union: different zones of integration...........................29

3 Schengen Agreement: gradual enlargement and multi-speed integration............32

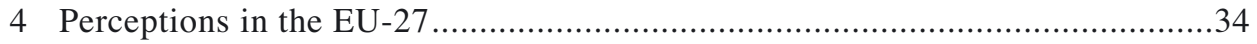

5 Perceptions in seven EU countries of Central Europe ......................................41

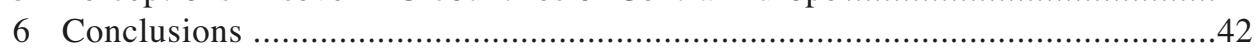

7 References

\section{Zusammenfassung}

Die Europäische Union der verschiedenen Geschwindigkeiten: Das Schengen-Abkommen und Wahrnehmungen seiner Räumlichkeit in Mitteleuropa

Der Beitrag befasst sich mit Wahrnehmungen der Reisefreiheit, wie sie durch das Schengen-Abkommen begründet wurde. Dieses Abkommen hat sich graduell im institutionellen Kontext der Europäischen Union (EU) mit ihren verschiedenen Geschwindigkeiten entwickelt. Der Schengen-Prozess führte seit der Mitte der 1980er Jahre zu einer schrittweisen Erweiterung der Schengen-Zone. Eine statistische Multivarianzanalyse der öffentlichen Meinung in 27 EU-Ländern über die Reisefreiheit im Schengenraum und die Kontrolle der EU-Außengrenzen ergab zwei Wahrnehmungskomponenten, nämlich "positive Einschätzung” und "praktische Nutzung”, und ermöglichte es, vier Haupttypen der Wahrnehmung in den EU-27 zu unterscheiden: positive, periphere, praktische und negative Wahrnehmung. Eine Korrelationsanalyse erbrachte gegensätz-

\footnotetext{
* Prof. Petr DostáL, M.A., Ph.D., Department of Social Geography and Regional Development, Faculty of Science, Charles University in Prague, Albertov 6, CZ-12843 Praha 2; e-mail: petr.dostal@natur.cuni. $\mathrm{cz}$, http://www.natur.cuni.cz/geography/department-of-social-geography-and-regional-development/
} 
liche öffenliche Meinungen in den alten und neuen Mitgliedsländern. Eine detaillierte Untersuchung der Wahrnehmung in den sieben mitteleuropäischen Mitgliedsstaaten bestätigte diese Ergebnisse.

\section{Summary}

The paper highlights perceptions of free cross-border movement of people regulated by the Schengen Agreement. The Agreement had developed gradually in the multispeed institutional context of the European Union (EU). The Schengen process led since the mid-1980s to a stepwise enlargement of the Schengen Area. A multivariate statistical public opinion analysis across 27 EU countries concerning free cross-border movement of people and control of external EU borders specifies two components of perceptions, i.e. positive valuation and practical use, and enables to distinguish four major types of perceptions in the EU-27: positive, peripheral, practical and negative perception. A correlation analysis revealed public opinion cleavages between old and new member countries. Detailed comparison of differences in perception in seven member countries forming the region of Central Europe supported these findings.

\section{Introduction}

This paper presents perceptions of spatiality as regards key aspects of the Schengen Agreement across 27 countries of the European Union (EU) and focuses later on perceptions in seven EU countries of Central Europe. At first, however, it considers the institutional context of the EU in detail, since it is this context and the multi-speed development of the EU in which the Schengen Agreement among more than 27 countries had been developing.

The Schengen Agreement as such is a significant example of the multi-speed character of the EU. Accordingly, the paper provides an overview of the changing multi-speed context of the EU in relation to the Schengen process that has resulted in free movement of people across borders of all signatory states. Between them border controls and custom formalities have been abolished, while the external borders of the Schengen Area are guarded even stricter. In an initial stage of the Schengen process starting in the mid-1980s, the Agreement was developing outside the then existing EU treaties. Later it became an important part of the Amsterdam Treaty (1997). The Schengen Agreement is currently shared by 31 signatories exceeding EU membership.

Later, this paper presents results of a multivariate statistical analysis of perceptions in 27 EU countries as regards freedom of movement of people within the Schengen Area and its consequences. These perceptions were derived from the Standard Eurobarometer Survey No. 77, which has been carried out in all EU member countries between 12 and 27 May 2012. This general survey is followed by a closer look at a sub-set of seven member countries forming the region of Central Europe, i.e. Germany, Austria, Czechia, Poland, Slovakia, Hungary and Slovenia. 


\section{Multi-speed European Union: different zones of integration}

The institutional context of the EU regarding the Schengen Agreement is complex. It has evolved gradually since the mid-1980s. The current EU faces problems of identity and cultural differences between the 27 societies concerned (see also Musil 1994). Since a well-integrated supranational (EU-wide) European polity (see DostáL 2010a) is missing, cultural and political life is still largely evolving within the boundaries of individual member states. Only supranational economic interdependencies are developing rapidly and dominate European integration and cross-border interactions (see also WASTL-W ALter 2011). They are also obvious with the long trajectory of the Schengen Agreement.

The differentiated character of the EU development arises firstly from the division of competencies, responsibilities and associated policies between the EU level and the level of national governments. Secondly, it evolves from the willingness of some governments to deepen EU integration, while others see no reasons for further deepening, or at least wish to postpone participation in common decision-making and associated policies. Consequently, specific clauses were added to the EU treaties and variable procedures of implementing legislation were accepted - often resulting in a multi-speed development (Dostál 2010a, pp. 24-27). Multi-speed development in turn results in a belt-like structure of diffusion.

As regards the Schengen Agreement, five major zones can be identified (DostÁL 2010a): (1) a zone of deepest integration, composed of member states willing to "pioneer" and form a core group in the EU - such as members of the Eurozone; (2) a zone of intensive integration, including member states forming a peripheral group of the EU outside the Eurozone; (3) a zone of limited integration and cooperation, that includes states which adopted some EU rules and take part in a variety of programmes without being formal EU members - such as members of the 1994 European Economic Area or, importantly, members of the Schengen Area (Norway, Iceland, Switzerland and Liechtenstein); (4) a zone of EU candidate countries or associated states; (5) a zone of countries involved in so-called EU neighbourhood policies.

There is an extended literature on the diversity of perspectives regarding the EU's institutional and procedural context (see TAYLOR 1991; ROSAMOND 2000; CHRYSSOCHOOU 2000; Costa \& Magnette 2003; Jönsson et al. 2000; Schmidt 2002; Morgan 2005; Dostál 2010a, pp. 27-32). Two kinds of perspectives have dominated the debates, i.e. supranational and intergovernmental perspectives.

\subsection{Supranational perspectives}

Supranational perspectives are basing on the pivotal claim that integration must focus primarily on the creation of common institutions representing independent authorities with important competencies in policy- and decision-making. Emphasis is being laid also on the ability of EU institutions to impose decisions and procedural rules on member states (RosAmond 2000; Morgan 2005). These aims are to be approached continuously and gradually as a deepening process (BERGGRUEN \& GARDELS 2013). The 
decision-making power of common institutions is to expand from economic affairs to political and social policy-making and, in the case of the Schengen Agreement, to home and immigration affairs.

These perspectives follow a largely formalist and normative view that is not so interested in the actual roles of EU institutions and national actors and their real behaviour or in differences in perceptions of EU development by national electorates. It does not sufficiently develop concepts in terms of the existing multi-level nature of policy- and decision-making that is so typical for EU reality (Rosemond 2000, pp. 105-129; Morgan 2005; Dostál 2010a).

Another key feature of these perspectives is that they tend to be Euro-optimistic and use various aspects of a federal system as norms for evaluations of EU developments. Their normative starting points tend to undervalue the role of a wide range of interest groups in actual EU operations, as well as the existence of a division between national elites and public opinion related to EU integration in many member states. As regards the Schengen Agreement, supranational perspectives tend to exaggerate the localisation of decisions at the EU level, i.e. with the European Commission and the European Parliament.

\subsection{Intergovernmental perspectives}

Intergovernmental perspectives stress the importance of nation states and, consequently, are closer to reality as regards EU institutional and procedural developments (Moravcsik 1998; Rosemond 2000). National preferences and strategic bargaining processes among EU countries are central in their considerations taking into account much empirical material from actual EU operations. They claim that national political interests are to being articulated by EU member countries based on domestic political debates, through national and supranational coalitions, social and cultural groups, lobbying and political-economic competition. An in-depth analysis of domestic politics is seen as an indispensable prerequisite before strategic interactions among member states can be defined. Supranational laws at the EU level are thus classified as reflecting interests of the most powerful member states - usually considered to be Germany, France and the United Kingdom (see also Wessels 1998; Dinan 2005; Hix 2005).

Certainly, intergovernmental perspectives provide useful interpretations of the EU institutional and organisational context in which the Schengen Agreement has been developing since the mid-1980s.

\subsection{Confederal consociational perspective}

The current EU system, however, can rather be understood as a confederal-consociational system. According to this perspective, the EU is a multi-faceted, confederal compact of nation states with some key consociative features (see also TAYLOR 1991; Chryssochoou 2000; Jönsson et al. 2000, pp. 124-125; Costa \& Magnette 2003). The 
confederal-consociational perspective provides a basis for more realistic and sufficiently complex interpretations of the EU development and the Schengen process than the two preceding perspectives. The term confederal refers to the system of institutions and procedures fixed by the treaties. This system enables the member states on the one hand to protect their vital interests by the possible use of a veto, while on the other a certain consensus can be achieved through consociative endeavours.

By the term consociation, processes of co-operative, joint decision-making among national representatives at the EU level are emphasised. The term implies the wellknown defining characteristics of consociation (Dostál 2010a, pp. 30-31), i.e. segmental autonomy (sovereignty) of member states; a government-like institution (the European Commission), in which the political elites of the segments (member states) are represented; proportional representation of member states in central EU institutions as well as - not the least important - the veto right of member states against majority decisions (see Costa \& Magnette 2003). The territorial boundaries of member states constitute segmental boundaries of national populations and the domestic scope of national political elites. Significantly, the term segmental also conveys the message that each member state has its own cultural system, which can be defined as "the subjective system of a society's institutions: the beliefs, values and knowledge, and skills that have been internalized by the people of a given society" (INGLEHART 1997, p. 15). Recognition of the key importance of national cultural systems is also essential for any specification of spatiality as regards public opinion on the Schengen Agreement and the Schengen Area.

The European Council of heads of national governments has the power to overrule the Council of Ministers and the European Parliament also regarding the Schengen Agreement. The Council of Ministers is the law-making institution of the EU to which each member country sends its representative. In fact, there are several Councils of Ministers dealing with individual sectors of policy-making including juridical and home affairs related to issues of the Schengen Agreement. Depending on the issues concerned, decisions can be taken by simple majority voting, by qualified majority voting or unanimously (Kostakopoulou 2000; DinAN 2005). By some mechanisms majority decision-making is limited, such as by compensations and package deals resulting in proportional outcomes, by a variety of modes of derogation or opt-outs (i.e. differentiated integration tools used in the Schengen Agreement, e.g., by the United Kingdom or Ireland) which make it possible to maintain decisive features of member-states sovereignty (see further DostáL 2010a). Therefore, decisions taken in the confederal and powerful European Council as well as in the Council of Ministers are decisive for the Schengen Agreement (see also Kostakopoulou 2000; Samers 2004; Hix 2005).

Looking at the character of the EU institutional and organisational context from the confederal-consociational perspective, it is possible to draw the conclusions that an EU-wide public sphere is not sufficiently developed and a new well-integrated European polity is not yet emerging. Accordingly, investigations into differences in the public opinion of member countries may be useful for further research. 


\section{The Schengen Agreement: gradual enlargement and multi-speed integration}

Enthusiasm in the mid-1980s for deepening European integration in the territorial core of the European Communities (EC) formed by Western Germany, France, Belgium, the Netherlands and Luxembourg led to first steps of abolishing border checks among the countries involved. In June 1985, the five countries formed a "pioneering" group and signed in Schengen (Luxembourg) an initial agreement. It took five years of intergovernmental negotiating before they passed so-called Schengen II. Schengen II enabled to implement measures for checkless border crossing at any point for persons travelling between the states involved (SAMERs 2004).

The same Agreement made it necessary to establish effective border control along the external borders of the Schengen Area. It also involved standardisation of procedures concerning home affairs regarding asylum, visas, illegal migration, police and judicial cooperation as well as a common information system.

The fact that the Schengen conventions evolved in 1990 as an intergovernmental framework and not as a part of EU treaties, underlines the great sensitivity of the Schengen process in domestic political discussions in the countries involved (MITSILEGAS 2002).

Between 1990 and 1992, Italy, Spain, Portugal and Greece joined the Schengen Area and significantly enlarged the initial pioneering group of countries. The 1992 Maastricht Treaty added the justice and home affairs sectors to the EU. In 1995, a next major enlargement took place, when the Nordic countries, i.e. Denmark, Sweden, Finland, Norway and Iceland, joined the Schengen Area.

The 1997 Amsterdam Treaty incorporated the Schengen Agreements into the core of European integration as a further step in the multi-speed development of the EU (Kostakopoulou 2000), and largely maintained unanimity in decision-making with regard to Schengen Area affairs.

Various opt-outs and protocols attached to the Agreement in accordance with the general principle of differentiated integration document the continued sensitivity of Schengen issues in domestic political discussion in the member states. After the May 2004 and January 2007 enlargements, the citizens of the new member states could not immediately enjoy full freedom of cross-border movement. They had to accept transitional periods of limited freedom (S AMERs 2004; Hix 2005).

Thus, the Schengen Area still functions largely within an intergovernmental framework, but within the context of the confederal-consociational system of the current EU following the historical trajectory of multi-speed development of a gradually enlarging Union (Mitsilegas 2002; Dostál 2010a).

The Schengen Agreement has also introduced the Schengen Visa allowing nonEU citizens free movement between all signatory countries with a single document. Additional visas are required for non-Schengen countries like the United Kingdom and Ireland.

An important component of the Schengen Agreement is the Schengen Information System enabling information exchange between national police forces concerning a number of issues, but especially on undesirable persons attempting to enter the Schen- 
gen Area. Trafficking and smuggling of persons from third countries belong to the most difficult problems (see the assessment of the case of Czechia in DrbohlaV et al. 2013). The United Kingdom and Ireland refused to sign up to the Schengen Information System. With the United Kingdom, the idea was influential that the system could undermine the country's sovereignty (SAMERs 2004; DinAN 2005; GidDEns 2007). At the intergovernmental negotiations related to the Amsterdam Treaty, however, both Ireland and the United Kingdom agreed to participate in common policy- and decisionmaking concerning police co-operation (KostAKOPOULOU 2000).

When it comes to highlight perceptions of the Schengen Agreement and its area in terms of spatiality it is useful to refer first to relevant recent literature on this topic. BECK (2006) introduces the concept of "cosmopolitization" which "means the disappearance of the closed society for good. But this is not felt as liberation by the majority of people, who instead see their world in decline. People who have succeeded with great difficulty in orienting themselves in the labyrinths of a closed society based on sharp opposition between us and them, inside and outside, national and international, are now suddenly faced with the contradictions of a tolerant form of society and a liberty they can neither comprehend nor live with, which reduces them to strangers in their own land ...". The problem is not boundarylessness, but that boundaries are no longer being drawn solely along national lines (2006, pp. 109-110).

Commenting on BECK he is firstly right in hinting at the interrelationships between "cosmopolitization" and movement of people across European societies. It appears that cross-border movement tends to strengthen emerging "cosmopolitan" values spreading across European societies. Secondly, he also seems to be correct in his emphasis on difficulties with the traditional roles of nation states, which are increasingly involved into intergovernmental affairs and European integration processes that are tending to shift perceptions of relevant political territories upwards in a process of re-scaling (CLARK \& JonEs 2008, 2013). Therefore, also O'Dowd stated that "the European project is reconfiguring borders as both frontiers and borders" (2002, pp. 32). Thirdly, BECK emphasises the importance of public opinion surveys, when they reflect cross-national differences as regards the importance of national and European ("cosmopolitan") identities.

Sсотт (2011) proposes a similar research orientation conceptualising the Europeanisation process in terms of "transport of European values" across the EU countries. He also notes that "while the space within the EU is being gradually integrated, a border is being drawn around the EU-27 in order to consolidate it as a political community and thus manage regional heterogeneity, core-periphery contradictions and politicalorganisational flux" (p. 136). Also PAASI (2001) rightly argued that European identity is not predetermined, but continuously redefined. Importantly, regarding re-scaling tendencies in articulations of territorial political and cultural identities, O'DowD (2002) stressed that EU-wide co-operation and the creation of democratic border regimes of the Schengen countries are supporting a supranational European identity.

Accordingly, these considerations on the re-scaling of perceptions of spatiality may result in the conclusion that the following four are key questions in this context: (1) Do people participate in free cross-border movement within the EU? (2) How do they 
perceive and valuate cross-border movement? (3) Do they perceive free cross-border movement as a positive result of EU integration? (4) Do they perceive control of the external Schengen border as an efficient practice of EU-wide political co-operation?

\section{Perceptions in the EU-27}

Table 1 presents five indicators reflecting public opinion related to cross-border movement and control of external borders of the current Schengen Area. The indicators are derived from the Standard Eurobarometer survey No. 77 carried out in May 2012 in the (at that time) 27 countries of the EU and organised by the Directorate General for Communication of the European Commission in Brussels [Brussel/Bruxelles]. The survey is based on representative samples of population older than 15 years. The sample size is usually 1,000 respondents, in the United Kingdom 1,300 and in Germany 1,500 respondents. In the micro-states Luxembourg, Malta and Cyprus only 500 respondents were involved. The correlation matrix of five indicators is analysed by the help of principal component analysis (see Rummel 1970; Dostál 2010a, pp. 54-60). The indicators represent average values of answers for each of the 27 samples. Thus, the principal component analysis explores cross-national perceptions in public opinion across the 27 member states. Our analytical approach will attempt to identify coherent systematic tendencies.

The results document the existence of two components. The structure of loadings on the first component clearly shows practical use of free cross-border movement. There is a high positive component loading $(0.905)$ of the indicator of frequent visits of people in other EU countries. Another high loading (0.922) has the opinion that people benefited from no or less border control. The next-significant loading (0.649) represents the opinion that the EU means personal freedom of travel, study and work. However, there is also a lower, but still significant positive loading of 0.419 representing the opinion that there is not enough control at the external EU borders.

To the second component we assign the title "positive valuation". There is high positive component loading (0.930) of the opinion that one of the most positive results of EU integration has been free movement of people, goods and services. Another high positive loading $(0.603)$ has the opinion that the EU means personal freedom to travel, study and work. However, there is also a very significant negative loading $(-0.778)$ representing the opinion that there is not enough control at the external borders of the EU.

It is significant that the two mutually independent (i.e. uncorrelated) components show very similar results. In addition, it is possible to draw at least five other important conclusions.

Firstly, the average level of frequent cross-border visits to other EU countries is relatively low. The EU average of $18 \%$ with the first opinion indicator suggests that people are in general not so much inclined to visit other EU countries at several occasions during a year. Differences between countries are, however, remarkable. It hardly 
surprises that Luxembourg is indicating the highest level of $73 \%$. This micro-state is surrounded by countries forming the economic and political core of the EU. Frequent cross-border visits are, however, also typical for citizens of Denmark (50\%) and the Netherlands $(45 \%)$. The lowest level of integration by travelling $(8 \%)$ document the geographically isolated countries Cyprus, Greece and Portugal in the European South.

Secondly, the key loading on the component of practical use of cross-border movement is the opinion that citizens of the EU countries benefited from this basic freedom organised by the Schengen Area regime. The EU average of this opinion is $44 \%$. It has a vast majority in Luxembourg (83\%), and also high one in the Netherlands $(67 \%)$. Low levels (23\%) occur in Romania and Bulgaria. This is not surprising, if one takes into account the multi-annual postponement of the Schengen regime. The lowest level, however, and this quite surprisingly, represents Hungary (only 18\%).

Thirdly, an important indicator of upward re-scaling tendencies in the perceptions of the EU is the opinion that the complex of EU countries means personal freedom to travel, study and work anywhere in the EU countries. Compared to the EU average of this perception $(41 \%)$, Estonia (67\%) and Luxembourg $(63 \%)$ show significant positive deviations. This contrasts to Italy (26\%) and the United Kingdom (27\%) at the lower end of the scale.

Fourthly, the opinion claiming that the EU provides not enough control at its external borders is also significant. The EU average of this perception is not high (16\%), but must not be neglected. The highest level occurs in Austria (41\%), a country surrounded by Schengen states, followed by Cyprus (31\%). The lowest levels (3\%) occur - significantly enough - in Latvia, Lithuania and Poland - all bordering nonSchengen countries and responsible for external borders.

\begin{tabular}{|l|c|c|}
\hline Indicators & $\begin{array}{c}\text { Component } \\
\text { "practical } \\
\text { use" }\end{array}$ & $\begin{array}{c}\text { Component } \\
\text { "positive } \\
\text { valuation" }\end{array}$ \\
\hline $\begin{array}{l}\text { Last twelve months visited another EU country on } \\
\text { several occasions (QD12.1), EU=18\% }\end{array}$ & 0.905 & -0.119 \\
\hline $\begin{array}{l}\text { Benefited from no or less border control (QD13.1), } \\
\text { EU=44\% }\end{array}$ & 0.922 & -0.025 \\
\hline $\begin{array}{l}\text { The most positive result of the EU - free movement of } \\
\text { people, goods and services, first answer (QD8a), EU=24\%) }\end{array}$ & 0.103 & 0.930 \\
\hline $\begin{array}{l}\text { The EU means personally freedom to travel, study and } \\
\text { work anywhere in the EU (QA15), EU=41\% }\end{array}$ & 0.649 & 0.603 \\
\hline $\begin{array}{l}\text { The EU means personally not enough control at } \\
\text { external borders of the EU (QA15), EU=16\% }\end{array}$ & 0.419 & -0.778 \\
\hline
\end{tabular}

Notes: varimax rotation; represented variance: component $1=45.542 \%$, component $2=37.068 \%$; own calculation

Tab. 1: Principal components of public opinion articulations regarding cross-border free movement (Standard Eurobarometer 77, fieldwork 12-27 May 2012; $\mathrm{N}=27$ ) 
Fifthly, there is the opinion that the most positive result of the EU is free movement of people, goods and services. This indicator has an EU average of $24 \%$ and is the leading loading on the component of positive valuation. The average may seem to be low. It has to be mentioned, however, that this indicator gives the share of the first answer in a larger set of questions concerning all possible most positive results of EU integration such as the maintenance of peace or the introduction of the Euro. The highest levels of this opinion show Latvia (45\%) and Bulgaria (42\%), the lowest France $(17 \%)$ and Belgium (18\%), while in a larger number of the EU countries the percentage is close to the average.

It is possible to estimate scores of individual countries related to the two components (see Rummel 1970). They can serve for the statistical construction of a basic typology of EU countries as it is done in Table 2. It must be stressed that the two components as well as the scores of the countries with these components, are uncorrelated, thus statistically independent and, therefore, suitable for typology construction. The typology distinguishes four primary types defined by thresholds.

\begin{tabular}{|l|l|l|}
\hline $\begin{array}{l}\text { Levels of positive } \\
\text { valuations and } \\
\text { practical use }\end{array}$ & $\begin{array}{l}\text { Lower levels of positive } \\
\text { valuations of the Schengen } \\
\text { Agreement (below principal } \\
\text { component score) }\end{array}$ & $\begin{array}{l}\text { Higher levels of positive } \\
\text { valuations of the Schengen } \\
\text { Agreement (above principal } \\
\text { component score) }\end{array}$ \\
\hline $\begin{array}{l}\text { Higher levels of practical } \\
\text { use of the Schengen Agree- } \\
\text { ment (above zero principal } \\
\text { component score) }\end{array}$ & $\begin{array}{l}\text { Practical perception } \\
\text { Luxembourg, Belgium, } \\
\text { Germany, Austria, Denmark }\end{array}$ & $\begin{array}{l}\text { Positive perception } \\
\text { Sweden, Finland, Estonia, } \\
\text { Latvia, The Netherlands, } \\
\text { Czechia, Slovenia, Slovakia }\end{array}$ \\
\hline $\begin{array}{l}\text { Lower levels of practical use } \\
\text { of the Schengen Agreement } \\
\text { (below zero principal } \\
\text { component score) }\end{array}$ & $\begin{array}{l}\text { Negative perception } \\
\text { Greece, Cyprus, Malta, Spain, } \\
\text { Portugal, France, Italy, } \\
\text { United Kingdom, Hungary }\end{array}$ & $\begin{array}{l}\text { Peripheral perception } \\
\text { Romania, Poland, Bulgaria, },\end{array}$ \\
\hline
\end{tabular}

Note: Own calculation

Tab. 2: Typology of public opinion articulations regarding free cross-border movement (Standard Eurobarometer 77, fieldwork 12-27 May 2012; N=27)

Higher levels of both positive valuations and practical use component scores indicate the public opinion in eight EU countries. We call this set of opinions positive perception. The group of countries corresponding to this set includes Scandinavian (Sweden and Finland) and Baltic countries (Estonia and Latvia) as well as the Netherlands. It is interesting to see that the Scandinavian countries tend to perceive cross-border movement in positive terms in spite of their peripheral position within the Schengen Area. Positive perception of free cross-border movement is also strong in Czechia, Slovakia and Slovenia. The more central position of these countries in the overall spatial configuration of the EU seems to explain this attitude.

Higher levels of positive valuation and lower levels of practical use characterise public opinion in five countries. We title this set of opinions peripheral perception. All countries except one (Poland) are located in peripheral parts of the EU. It is obvious 
that their peripheral location within the EU constrains cross-border travelling, and also influences the perception of practical possibilities regarding cross-border movement.

Higher levels of practical use and lower levels of positive valuations of cross-border movement are typical for five countries. These opinions seem to be based on practical perception. In spatial terms, the grouping forms a continuous core region of the EU. Not surprisingly, Luxembourg is a member of this group. This micro-state profits significantly from the abolition of border control. Luxembourg, Germany, Belgium and Austria belong to the geographical core of the enlarged EU. It is not surprising that citizens in these countries perceive free cross-border movement as a condition, which clearly improves their ways of life. On the other hand, however, it seems that this type of practical perception also conveys another message. It indicates that the inhabitants of these countries tend to be critical regarding the control of external Schengen borders. Thus, on the one hand, this type of perception indicates intensive use of freedoms, but at the same time tends implicitly to attribute responsibilities to EU countries along the external Schengen border in protecting them.

Finally, the fourth type is characterised by low levels of both practical and positive valuations. This negative perception group includes nine countries. Five of them are located at the southern fringe of the EU, while the United Kingdom and Hungary are also part of it. It appears that these negative perceptions of both the practical use and the basic freedom of cross-border movement are typical for countries confronted with long-lasting pressures of illegal immigration (SAMERS 2004). This is especially true for the Mediterranean EU countries Italy, Malta, Cyprus, Greece and Spain confronted with illegal immigration from African countries.

Further statistical analysis is based on the interpretation of a correlation matrix of the scores of the two components and four selected explanatory variables (see Tab. 3). The statistical analysis so far suggested some systematic tendencies useful for further correlation analysis. Table 3 presents correlations (Pearson correlation coefficients) indicating that some estimated relationships are substantial and interesting in the light of earlier considerations. Obviously, no correlation exists between the component scores, because these indicators originate from uncorrelated dimensions documented in Table 1. The estimated relationships shown seem to allow the following interpretations.

\begin{tabular}{|l|c|c|c|c|c|c|}
\hline Indicators & (1) & (2) & (3) & (4) & (5) & (6) \\
\hline (1) PCA score positive valuation (EB77) & 1.000 & & & & & \\
\hline (2) PCA score practical use (EB77) & 0.000 & 1.000 & & & & \\
\hline (3) years of EU membership (2011) & -0.599 & 0.151 & 1.000 & & & \\
\hline (4) GDP per capita in PPS (2011) & -0.466 & 0.605 & 0.647 & 1.000 & & \\
\hline (5) immigrants do not integrate (SEB380) & -0.145 & 0.476 & 0.155 & 0.2290 & 1.000 & \\
\hline (6) net support EU enlargement (EB77) & 0.679 & -0.350 & -0.712 & -0.654 & -0.421 & 1.000 \\
\hline
\end{tabular}

Note: Pearson correlation coefficients; own calculations

Tab. 3: Correlations between principal component scores and selected explanatory variables 
Firstly, cumulated experience of the EU societies in terms of number of years of their membership and participation in the EU multi-speed integration processes is an important explanatory factor, because it incorporates differences in experience of the societies concerned resulting from the recent enlargements (JORDAN 2004; DosTÁL 2010a). In addition, this indicator also represents time differences in cumulated experience wit the Schengen Area regime. There is a clear substantial negative correlation (-0.599) between the scores on the component of positive valuation and the number of years of EU membership. Figure 1 shows this significant negative relation (determination of $35.9 \%$ ) and indicates the existence of a perceptions cleavage between, on the one hand, the new member countries and the old member states on the other.

Figure 1 also highlights the extreme positions of Latvia (LV) and Cyprus (CY) in the group of twelve new member countries. There is also the extreme position of Austria (AT) already mentioned before. In the group of the six founding countries of the EU only the Netherlands (NL) are on the positive side of the component. It is remarkable that the powerful member states France (FR), United Kingdom (UK) and Germany (DE) show extremely low positive perceptions of free cross-border movement. The

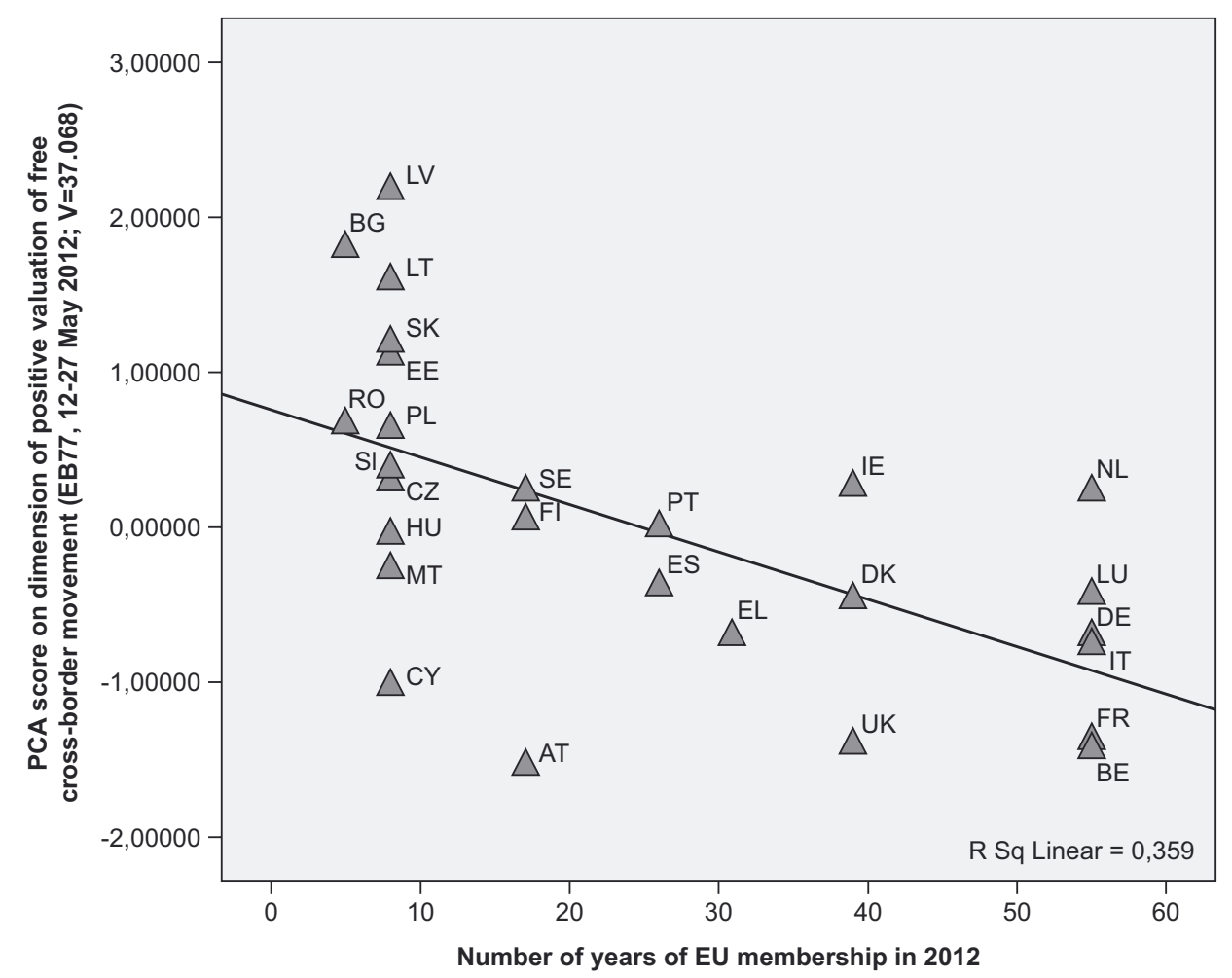

Fig. 1: Correlation between scores on the component of positive valuation of free cross-border movement and the number of years of EU membership 
evident cleavage between the new and old member countries indicates geopolitical tensions that split the enlarged EU (see also SAmers 2004; Dostál 2010a).

Secondly, there is a lower, but interestingly enough, positive correlation between the score on the dimension of practical use and the opinion that immigrants do not want to integrate into the societies of the EU countries. This latter opinion is derived from Special Eurobarometer No. 380, which was carried out between December 3 and 18, 2011, applying the survey methodology used by Standard Eurobarometer No. 77. Figure 2 shows a quite complicate pattern. It documents that a majority of countries clusters close to the high EU average of $73 \%$ indicating that this critical opinion regarding integration of immigrants spreads across EU societies. Eight countries occupy extreme positions in the diagram: Slovenia (SI), Austria (AT), Germany (DE), Luxembourg (LU), Slovakia (SK), Czechia (CZ), Belgium (BE) and Latvia (LV). It appears that in the EU countries mentioned critical attitudes as regards the adjustment of diverse immigrant groups clearly dominate and that immigrant cultures are in conflict with autochthonous cultural traits. This perception can have implications also on the socioeconomic integration of immigrants (INGLEHART 1997; GIDDENs 2007). However, it must

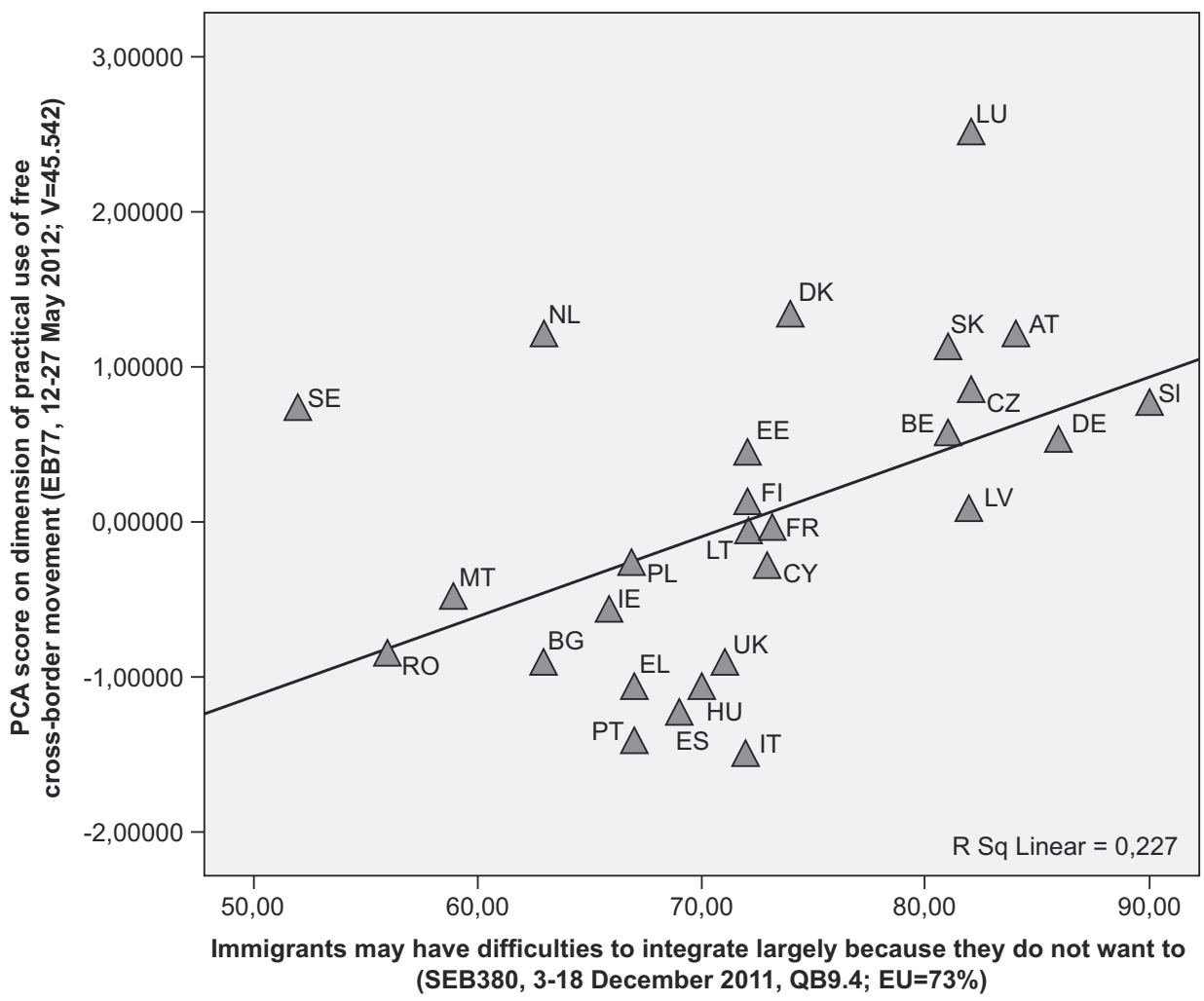

Fig. 2: Correlation between scores on the component of practical use and the opinion that immigrants largely do not want to integrate 
be emphasised that these opinions do not necessarily mean that immigrants have to assimilate and completely merge with the culture and identity of the receiver country.

Sweden and the Netherlands deviate extremely from the general tendency of this positive correlation. It seems that in these two largely post-materialist societies (see INGLEHART \& WELZEL 2005, pp. 59-63) important tolerant perceptions, attitudes and behaviours have developed regarding immigration issues.

Finally, Table 2 shows an interesting positive correlation (0.679) between scores on the dimension of positive valuation of cross-border movement and public opinion supporting further enlargement of the EU by new countries.

The indicator shown in Figure 3 is representing net support (i.e. from positive answers negative answers are subtracted) indicating that only in twelve EU countries support for further EU enlargement is higher than the opposing opinion. The EU average is a clear negative figure $(-17 \%)$. Statistical determination of the positive relationship is considerable $(45.2 \%)$. The diagram documents again the existence of a clear perception and public opinion cleavage between new and old member countries. Public opinions in eight new member countries indicate positive net support for further

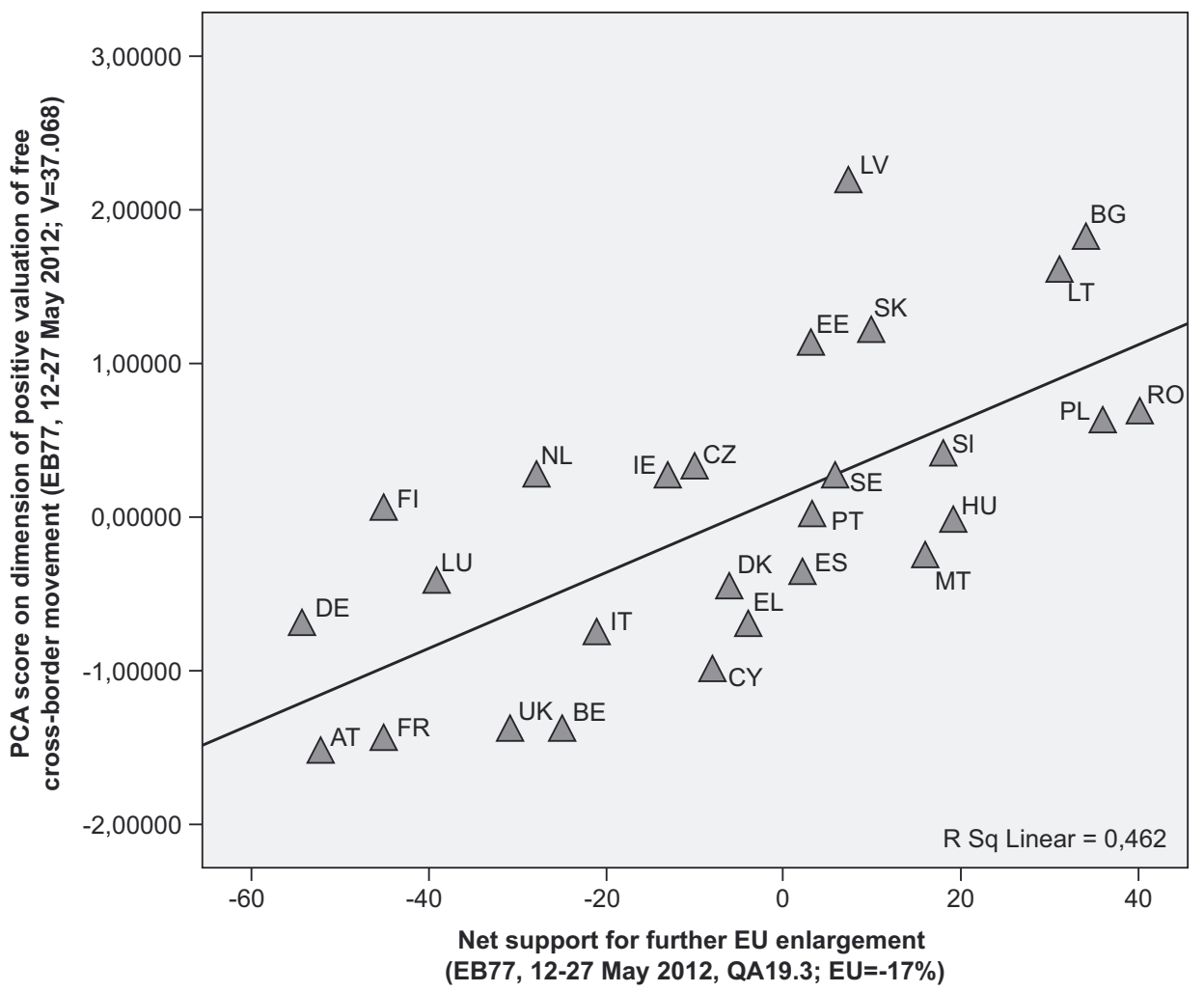

Fig. 3: Correlation between scores on the component of positive valuation of free cross-border movement and net support for further EU enlargement 
EU enlargement as well as a positive score on valuation of cross-border movement. Only Cyprus, Malta, Czechia and Hungary do not belong to this large group of new member countries with positive perceptions. Extreme positions in the diagram have public opinions in Austria (AT), Germany (DE), France (FR), Luxembourg (LU), the United Kingdom (UK) and Belgium (BE). These EU societies express very critical opinions regarding further EU enlargement associated with very low scores on positive valuation of cross-border movement. It is interesting to note that among them are the most influential EU members Germany, France and the United Kingdom - usually the decisive votes in intergovernmental negotiations concerning changes in the Schengen regime (Kostakopoulou 2000; Samers 2004). Accordingly, it can be assumed that the very negative opinion expressed by the electorates of these countries will be feeding back on future political decision-making and will complicate any further enlargement of the Schengen Area.

Table 3 reveals also other interesting correlations. There is, e.g., a clear positive relationship (0.606) between the principal component score representing practical use of free cross-border movement and the GDP in purchasing parity standards. This positive correlation indicates that perceptions of practical use are strong in rich EU countries with high economic performance. Given the interpretations of the three diagrams, it is clear that the correlation between the score on the component of positive valuation of free cross-border movement and the GDP indicator is negative $(-0.466)$.

Another expected strong negative correlation is that one between the number of years of EU membership and net support for further enlargement (-0.712). A similar negative correlation exists between the GDP indicator and the net support for further enlargement (-0.654) suggesting that richer EU countries will resist any further enlargement of the Schengen Area.

\section{Perceptions in seven EU countries of Central Europe}

After the multivariate statistical analysis and interpretation of perceptions in the set of $27 \mathrm{EU}$ member countries, the focus turns to a sub-set of countries forming the region of Central Europe. There is a long tradition of geographical research on this region. The classical study made by SinnHUBER (1954) indicated as the core of the region Austria and what is today Czechia. Other studies found delineations mostly including Germany, Austria, Czechia, Poland, Slovakia, Hungary and Slovenia (Lichtenberger 2000; Dostál \& Hampl 1996).

Table 4 presents perception data for the seven countries of Central Europe mentioned before and allows some interpretations. Already the analysis of the $27 \mathrm{EU}$ countries revealed a public opinion cleavage between old and new member states. Table 4 allows to specify this finding further.

As regards frequent visits to other countries, Austria and Czechia display the same high values of $36 \%$, closely followed by Slovakia and Slovenia. In Germany and Poland, the figures are lower, perhaps just as an effect of their larger territories. The 


\begin{tabular}{|l|c|c|c|c|c|c|c|}
\hline Indicators (\% of country samples) & DE & AT & CZ & PL & SK & HU & SI \\
\hline Visited another EU country last twelve months & 22 & 36 & 36 & 16 & 33 & 17 & 31 \\
\hline Benefitted from no cross-border control & 62 & 60 & 61 & 56 & 73 & 18 & 69 \\
\hline The most positive result EU: free movement & 23 & 23 & 35 & 30 & 39 & 25 & 31 \\
\hline The EU means freedom for travel, etc. & 50 & 50 & 50 & 45 & 58 & 44 & 51 \\
\hline The EU means not enough border control & 24 & 41 & 19 & 3 & 11 & 10 & 12 \\
\hline Immigrants do not integrate & 86 & 84 & 82 & 67 & 81 & 70 & 90 \\
\hline Net support for further EU enlargement & -54 & -52 & -10 & 36 & 10 & 19 & 18 \\
\hline
\end{tabular}

Sources: Standard Eurobarometer No. 77 (12-27 May 2012) and Special Eurobarometer No. 380 (3-18 December 2011

Tab. 4: Differences in public opinion in EU countries of Central Europe

case of Hungary, however, is surprising. Hungary has large minorities in neighbouring countries and frequent visits there would be a logical consequence.

Interesting differences across Central Europe appear as regards the opinion on benefits from free cross-border movement. Almost identical high appreciation is obvious for Germany, Austria and Czechia. The highest values, however, document Slovakia and Slovenia. Again, the value for Hungary is very low.

The opinion that the most positive result of the EU is the free movement of people, goods and services is strongly supported in the new member countries Slovakia, Czechia, Slovenia, Poland and much less in the old(er) members Germany and Austria, but also in Hungary. Support for the opinion that the EU means personally freedom to travel, study and work anywhere in the EU is slightly differently distributed: majorities support this opinion in Germany, Austria, Czechia, Slovakia and Slovenia.

Critical voices as regards a lack of control of external EU borders are most frequent in Austria (41\%), but also in Germany. This contrasts to the new member countries, except Czechia, which is in this respect close to Germany. This picture coincides with the distribution of critical stances opposite immigrants - the latter, however, showing much higher shares.

In addition, the issue of further EU enlargement divides Central Europe. In Germany and Austria, a negative opinion dominates and reaches levels of -54 and $-52 \%$, respectively. Second to them is Czechia with $-10 \%$. In the other four new member countries further enlargement is more popular, with Poland at the top.

A common feature of all these results is a cleavage between old and new member states, in which Czechia occupies a transitional position.

\section{Conclusions}

Departing from the Schengen Agreement being the result of the confederal and consociational system of the EU, this paper was analysing perceptions of EU and 
Central European EU member citizens as regards the Schengen regime based on recent Eurobarometer surveys.

Apparently, cross-border movement tends to strengthen tolerant "cosmopolitan" values in particular in the Scandinavian member countries, though it also seems that the tension between traditional roles of nation states and perceptions of a new European spatiality increases. Very obvious is the cleavage between old and new EU members. The citizens of old member countries use and appreciate the freedoms granted by the Schengen Agreement, but wish to have the external Schengen borders carefully guarded and dislike further EU enlargement. Quite in contrast, the population of new EU members takes less advantage of the internal Schengen freedoms, but is less critical as regards the guarding of external Schengen borders as well a further EU enlargement.

\section{References}

Beck U. (2006), Cosmopolitan Vision. Cambridge, Polity Press.

Beck U., Grande E. (2007), Cosmopolitan Europe. Cambridge, Polity Press.

Berggruen N., Gardels N. (2013), The next Europe. In: Foreign Affairs, 92, 4. pp. 134-142.

Chryssouchou D.N. (2000), Democracy in the European Union. London, Tauris Academic Studies.

Clark J., Jones A. (2008), The spatialities of Europeanisation: territory, government and power in "Europe". In: Transactions of the Institute of British Geographers, 33, 3, pp. 300-318.

Clark J., Jones A. (2013), The great implications of spatialisation: grounds for closer engagement between political geography and political science? In: Geoforum, 45, pp. 305-314.

Costa O., Magnette P. (2003), The European Union as a consociation? A methodological assessment. In: West European Politics, 26, 3, pp. 1-18.

DinAn D. (2005), Ever Closer Union. An Introduction to European Integration. Basingstoke, Palgrave Macmillan.

Dostál P. (2010a), Multi-Speed European Union: Differentiated Intergration and Spatial Development in Public Opinion (= Geographica Series, 6). Prague, Czech Geographic Society.

Dostál P. (2010b), Environment and regional cohesion in the enlarged European Union - differences in public opinion. In: AndĚL J., Bičík I., Dostál P., LipskÝ Z., Shahneshin S.G. (eds.), Landscape Modelling. Geographical Space, Transformation and Future Scenarios, pp. 45-60. New York, Springer.

Dostál P., Hampl M. (1996), Transformation of East-Central Europe: general principles under differentiating conditions. In: Carter F.W., Jordan P., Rey V. (eds.), Central Europe after the Fall of the Iron Curtain, pp. 113-128. Frankfurt am Main, Peter Lang.

Drbohlav D., ŠTYCh P., Dzurová D. (2013), Smuggled versus not smuggled across the Czech border. In: International Migration Review, 47, 1, pp. 207-238.

Giddens A. (2007), Europe in the Global Age. Cambridge, Polity Press.

Gillespie P., Laffan B. (2006), European identity: theory and empirics. In: Cini M., Bourne A.K. (eds.), Palgrave Advances in European Studies, pp. 131-150. Basingstoke, Palgrave.

Hix S. (2005), The Political System of the European Union. Basingstoke, Palgrave.

Inglehart R. (1997), Modernization and Postmodernization. Cultural, Economic, and Political Change in 43 Societies. Princeton, Princeton University Press.

Inglehart R., Welzel C. (2005), Modernization, Cultural Change, and Democracy. The Human Development Sequence. Cambridge, Cambridge University Press. 
Jönsson C., TägIl S., TöRnqvist G. (2000), Organizing European Space. London, SAGE Publications.

JoRDAN P. (2004), EU-Erweiterung und europäische Identität. In: Mitteilungen der Österreichischen Geographischen Gesellschaft, 146, pp. 43-60.

Kostakopoulou T. (2000), The "protective Union": change and continuity in migration law and policy in post-Amsterdam Europe. In: Journal of Common Market Studies, 38, 3, pp. 497-518.

Lichtenberger E. (2000), Austria. Society and Regions. Bad Vöslau, Grasl Druck und Neue Medien.

LiJPhART A. (1979), Consociation and federation: conceptual and empirical links. In: Canadian Journal of Political Science, 12, 3, pp. 499-515.

Mitsilegas V. (2002), The implementation of the EU acquis on illegal immigration by the candidate countries of Central and Eastern Europe: changes and contradictions. In: Journal of Ethnic and Migration Studies, 28, 4, pp. 665-682.

Moravcsik A. (1993), Preferences and power in the European Community: A liberal intergovernmentalist approach. In: Journal of Common Market Studies, 31, 4, pp. 380-399.

Moravcsik A. (1998), The Choice for Europe. Societal Purpose and State Power from Messina to Maastricht. Ithaca, Cornell University Press.

Morgan G. (2005), The Idea of a European Superstate. Public Justification and European Integration. Princeton, Princeton University Press.

MusiL J. (1994), Europe between integration and disintegration. In: Czech Sociological Review, 2,1, pp. 5-19.

O'Dowd 1. (2002), The changing significance of European borders. In: Regional and Federal Studies, 12, 4, pp. 13-36.

PAAsi A. (2001), "A borderless world". Is it only rhetoric or will boundaries disappear in the globalizing world? In: Reuber P., Wolkersdorfer G. (eds.), Politische Geographie. Handlungsorientierte Ansätze und Crical Geopolitics, pp. 133-145. Heidelberg, Heidelberger Geographische Arbeiten.

Rosamond B. (2000), Theories of European Integration. Basinstoke, Palgrave Macmillan.

Rummel R.J. (1970), Applied Factor Analysis. Evanston, Northwestern University Press.

SAMERS M. (2004), An emerging geopolitics of "illegal" immigration in the European Union. In: European Journal of Migration Law, 6, pp. 27-45.

Schmidt M.G. (2002), Der konsoziative Staat. Hypothesen zur politischen Struktur und zum politischen Leistungsprofil der Europäischen Union. In: Grande E., Jachtenfuchs M. (eds.), Wie problemlösungsfähig is die EU? Regieren im dynamischen Mehrebenensystem, pp. 33-58. Baden-Baden, Nomos.

Scott J.W. (2011), Borders, border studies and EU enlargement. In: Wastl-Walter D. (ed.), The Ashgate Research Companion to Border Studies, pp. 123-142. London, Ashgate.

Sinnhuber K. (1954), Central Europe - Mitteleuropa - Europe Centrale. An analysis of a geographical term. In: Transactions of the Institute of British Geographers, 20, pp. 15-39.

TAYLOR P. (1991), The European Community and the state: assumptions, theories and propositions. In: Review of International Studies, 17, pp. 109-115.

W Astl-Walter D. (ed.) (2011), The Ashgate Research Companion to Border Studies. London, Ashgate.

Wessels W. (1998), Flexibility, differentiation and closer cooperation. The Amsterdam provisions in the light of the Tindemans Report. In: Westlake M. (ed.), The European Union beyond Amsterdam. New Concepts of European Integration, pp. 76-98. London, Routledge. 